\title{
Population density, geographical distribution and habitat of Talaud bear cuscus (Ailurops melanotis Thomas, 1898)
}

\author{
TERRI REPI ${ }^{1,2, \boldsymbol{v}}$, BURHANUDDIN MASY'UD $^{3}$, ABDUL HARIS MUSTARI ${ }^{3}$, LILIK BUDI PRASETYO $^{3}$ \\ ${ }^{1}$ Program of Tropical Biodiversity Conservation, Graduate School. Institut Pertanian Bogor. Jl. Raya Dramaga, Kampus IPB Dramaga, Bogor 16680, \\ West Java, Indonesia \\ ${ }^{2}$ Department of Animal Husbandry, Universitas Muhammadiyah Gorontalo. Jl. Prof. Dr. H. Mansoer Pateda, Gorontalo 96181, Gorontalo, Indonesia. \\ Tel./fax.: +62-271-663375, `email: terrirepi@gmail.com \\ ${ }^{3}$ Department of Forest Resources, Conservation and Ecotourism, Faculty of Forestry and Environment, Institut Pertanian Bogor. Jl. Ulin Lingkar \\ Akademik, Kampus IPB Dramaga, Bogor 16680, West Java, Indonesia
}

Manuscript received: 23 September 2020. Revision accepted: 6 November 2020.

\begin{abstract}
Repi T, Masy'ud B, Mustari AH, Prasetyo LB. 2020. Population density, geographical distribution and habitat of Talaud bear cuscus (Ailurops melanotis Thomas, 1898). Biodiversitas 21: 5621-5631. The Talaud bear cuscus (Ailurops melanotis) has been reported from Sangihe (the largest island in the Sangihe Island group) and Salibabu (within the Talaud Islands). As an endemic species of Indonesia, this species is rare and there is no certainty regarding its precise geographic distribution or population size. This research aimed to estimate population density and provide the first preliminary data on its geographical distribution, as well as general description of its habitat. Our research shows that A. melanotis occurs on three islands: Salibabu Island, Nusa Island, and Bukide Island, and probably also exists in the Sahandaruman mountain on Sangihe Island. Our population surveys estimate, population density on each island as: Salibabu: $3.69 \pm 2.54 \mathrm{ind} / \mathrm{km}^{2}$, with an estimated total population of 28.95 individuals, Nusa Island: was $12.31 \pm 2.58 \mathrm{ind} / \mathrm{km}^{2}$, with an estimated population of 19.08 individuals, and Bukide Island: $7.17 \pm 1.79 / \mathrm{km}^{2}$, with an estimated population of 10.40 individuals. Information regarding population is a key guiding factor in conservation efforts, where population size is related to extinction risk (threat status) and its geographical distribution, this can help to determine conservation priorities for species or habitats.
\end{abstract}

Keywords: Ailurops melanotis, distribution, conservation, habitat, density, population

\section{INTRODUCTION}

The Sangihe and Talaud Islands are considered to be the farthest areas of endemicity centers in the Wallacea region, which have very high endemicity (Natus 2005). One of the endemic species in these two island clusters is the Talaud bear cuscus (A. melanotis), which, according to the International Union for Conservation of Nature (IUCN) is in a Critically Endangered status with a declining population trend (Flannery and Helgen 2016). The Zoological Society of London (ZSL) included this species as one of Evolutionarily Distinct and Globally Endangered species (EDGE) based on evolution, life history, and threat status (EDGE 2018). Therefore, this endemic cuscus represents an important global conservation priority (Martin et al. 2018). Within Indonesia, A. melanotis is protected according to the Republic of Indonesia Minister of Environment and Forestry Regulations.

This species is rare and there is no certainty about its geographical distribution and estimated population size (Riley 2002; Smith et al. 2012; Flannery and Helgen 2016). Heinsohn (2010), even concluded that the A. melanotis is a cryptogenic species whose origins are not known with certainty, and assumes that this species is an introduced animal, originating from the large island of Sulawesi and brought by humans to Salibabu Island as pets and protein sources.

Until now, the existence of A. melanotis is known to be distributed on Salibabu Island and possibly on Sangihe
Island, with a particular stronghold on Mount Sahendaruman (Riley 2002; Flannery and Helgen 2016). However, Flannery and Helgen (2016) state that, although it has been reported on Salibabu Island, and has been seen and photographed on Sangihe, no specimen is known to exist from here. Related to this, Flannery and Helgen (2016) suspected that the Talaud bear cuscus on Sangihe Island was the Sulawesi bear cuscus (Ailurops ursinus) given the island's proximity to the main island of Sulawesi. A brief survey on Salibabu Island by Riley (2002) did not find any individual cuscus, and an intense 120-day survey on Sangihe Island found only a single captive individual. However, recently there was a publication about daily activity and diet of A. melanotis on Salibabu Island by Repi et al. (2019), which confirmed the existence of A. melanotis here. But in general, until now the distribution assumptions and population status were based solely on local information.

Riley (2002) reports this species as being heavily hunted, with a declining and fragmented population within a small area of occurrence. Before this study, there were no data related to population, distribution, and habitat of A. melanotis, so this study aimed to address these research gaps.

Information about population is one of the key factors in conservation efforts, as population size is related to extinction risk (threat status) and its geographical distribution, this can help to determine conservation priorities for species or habitats (Tucker 2005). The 
management and conservation of effective wildlife populations require reliable estimation of the size or density of wild animal populations (Marques et al. 2013). The data can be used to evaluate and predict population trends, determining causes of declines, and be used to review listing status under threatened species legislation (Zipkin and Saunders 2017: Robinson et al. 2018). Leca et al. (2013) stated that accurate information about the status and trends of animal populations obtained from inventory and socio-ecological studies is a prerequisite for the success of wildlife conservation programs. Therefore, density estimation is integral to the effective conservation and management of wildlife (Burgar et al. 2018).

\section{MATERIALS AND METHODS}

\section{Study area}

Preliminary surveys were carried out at six locations: Karakelang Island, Salibabu Island, Kabaruan Island, Sangihe Island, Nusa Island, and Bukide Island, in the form of interviews and observation transects. However, population and habitat data collection was only carried out in the three locations where A. melanotis was found, namely: Salibabu Island (Talaud Islands Regency), Nusa Island and Bukide Island (Sangihe Islands Regency) (Figure 1). The preliminary survey and data collection were conducted over a one-year period between February 2016 and February 2017.

\section{Data collection and analysis}

Population surveys were completed using the strip transect sampling method (Norton-Griffiths 1978;
Subcommittee on Conservation of Natural Population 1981). The length of each transect was made according to the topography of the location, with a transect width of 30 $\mathrm{m}$ on both sides of the transect (total width of $60 \mathrm{~m}$ ). Transects locations were based on information from the locals and the results of the preliminary survey. Observations were made twice a day, at 06.00 am and $14.00 \mathrm{pm}$ by 2-3 observers for each transect. Data was collected regularly by walking on transects with an average speed of 1.5 to $1 \mathrm{~km} /$ hour. Collecting data on the distribution of $A$. melanotis populations was carried out simultaneously with population observations. The position of each individual or each group is recorded using a GPS receiver, then mapped using Arc GIS.

The population density of $A$. melanotis was calculated using data on the number of individuals observed in the transects. To analyze the data, the Subcommittee on Conservation of Natural Population (SCNP) (1981) formula was used as follows: $\mathrm{D}=\Sigma \mathrm{i} /(\mathrm{R} \times \mathrm{Ltot})$. Where: $\mathrm{D}$ $=$ density (individuals $/ \mathrm{km}^{2}$ ), $\Sigma \mathrm{i}=$ number of individuals, $\mathrm{R}$ $=$ replications, Ltot $=$ total area of observation $\left(\mathrm{km}^{2}\right)$. The total area of the observation (research area) was obtained from: $\mathrm{Ltot}=\mathrm{L} \times \mathrm{W}$. Where: Ltot $=$ total area of observation $(\mathrm{km} 2), \mathrm{L}=$ length of transect $(\mathrm{km}), \mathrm{W}=$ width of transect $(\mathrm{km})$. Estimation of cuscus population size was obtained by the formula: $\mathrm{P}=\mathrm{D} \times \mathrm{LREP}$. Where: $\mathrm{P}=$ estimated population (individuals), $\mathrm{D}=$ population density (individuals $/ \mathrm{km}^{2}$ ) and LREP $=$ representative habitat area. Representative habitat area is the area of forest suitable for cuscus habitat. This data is obtained based on the results of processing data on habitat characteristics and field surveys.
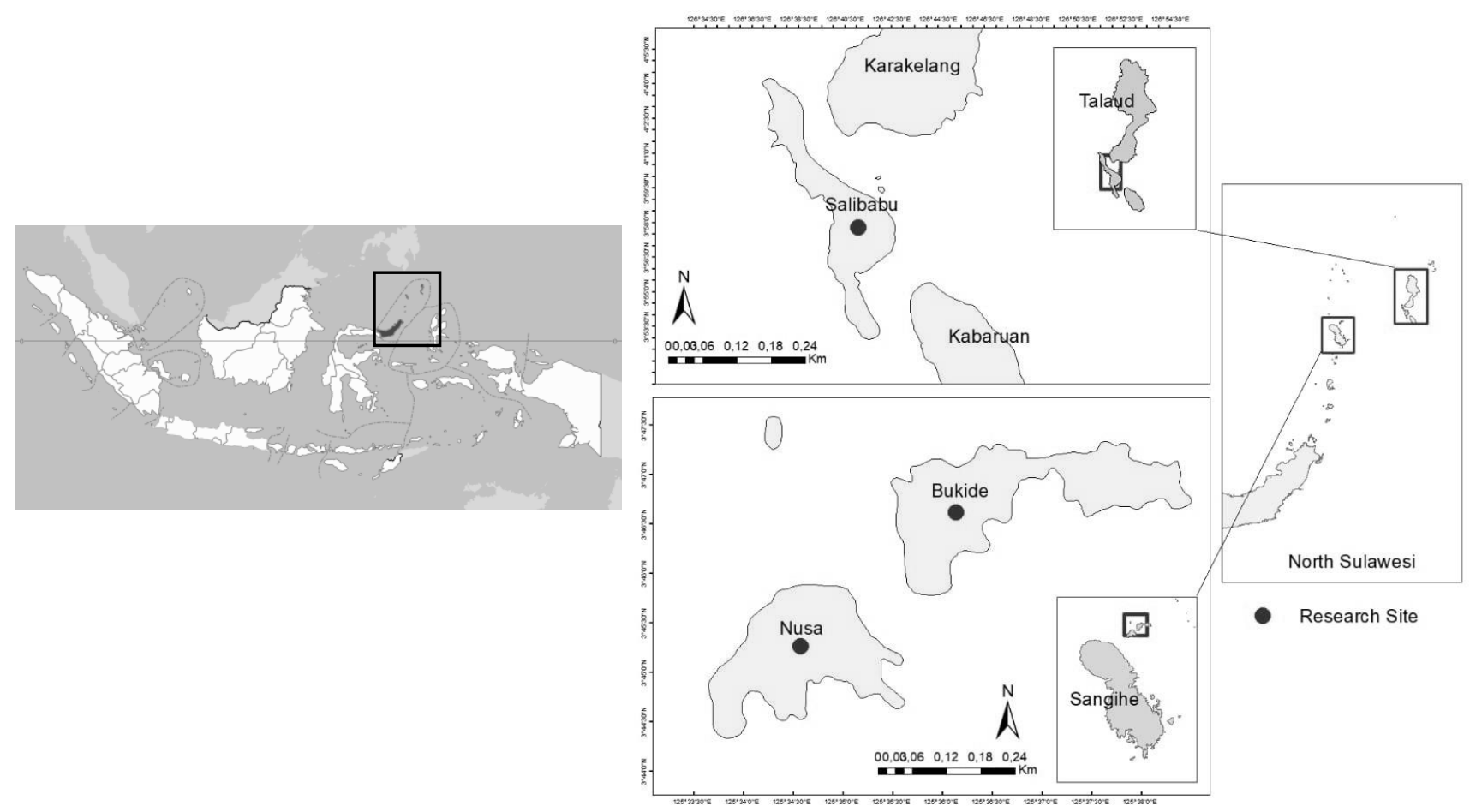

Figure 1. Map of Talaud bear cuscus (Ailurops melanotis) survey areas in the Sangihe and Talaud Islands, North Sulawesi, Indonesia 
Vegetation analysis used a sample plot in the form of line compartment method. A total of 27 vegetation survey plots were carried out with $20 \mathrm{~m} \times 20 \mathrm{~m}$ of each plot $(2 \mathrm{~m} \mathrm{x}$ $2 \mathrm{~m}$ for seedling level; $5 \mathrm{~m} \times 5 \mathrm{~m}$ for sapling level; $10 \mathrm{~m} \times$ $10 \mathrm{~m}$ for pole level and $20 \mathrm{~m} \times 20 \mathrm{~m}$ for tree level). On Salibabu Island, fifteen plots were completed, with six plots were completed on Nusa Island and Bukide Island. For data analysis, we examined: density, relative density, frequency, relative frequency, dominance, and relative dominance, then calculated to obtain the important value index (IVI) (Mueller-Dombois dan Ellenberg 1974; Odum 1993). The Shannon-Wiener diversity index was used to measure the diversity of vegetation species (Magurran 2004), for evenness of vegetation species in all sample plots used the Index of Evenness (Pielou 1966), and to measure the richness of vegetation species, the Margalef species richness index was used (Magurran 2004). The similarity of the species composition in each vegetation plots on each island was analyzed using the Bray Curtis index.

Besides population surveys, in order to find out the distribution of cuscus populations on six islands, interviews were conducted with local communities (specifically hunters and farmers who own agricultural land in forest areas), to indicate the presence of cuscus population that might have been missed by our surveys. The selection of respondents used the purposive sampling and snowball sampling method, with a deliberate sample selection involving key informants and then proceed to other informants based on previous information. Data processing uses Microsoft Excel, Statistical Product and Service Solutions (SPSS) program version 25.0, and Past program version 3.24 .

\section{RESULTS AND DISCUSSION}

\section{Habitat}

Vegetation

Based on the analysis of vegetation, it is known that the species with the highest importance value index for the tree level of the three islands are the same; Canarium asperum. While for the pole level, the species with the highest importance value index on Salibabu Island is Pimelodendron amboinicum, while on Nusa Island and Bukide Island, is Canarium asperum (Table 1). While, the average height of trees and poles on Salibabu Island is higher than that of Nusa and Bukide Islands (Table 2).

The high dominance of Canarium asperum explains the high encounters of cuscus on this tree; On Salibabu Island, 3 out of 11 encounters were observed, Bukide Island, two out of three encounters, and Nusa Island, two out of four encounters. This is also supported by Repi et al. (2019) who reported that $C$. asperum is one of the species most consumed by A. melanotis on Salibabu Island, apart from M. peltata and $C$. odorata.

Table 1. Number of plots, vegetation species, domination index, and the highest IVI on three islands

\begin{tabular}{llllll}
\hline \multirow{2}{*}{ Islands } & \multirow{2}{*}{ Variable } & \multicolumn{3}{c}{ Growth stage criteria } \\
\cline { 3 - 6 } & Seedling & Sapling & Pole & Tree \\
\hline \multirow{6}{*}{ Salibabu } & Number of plots & 15 & 15 & 15 & 15 \\
& Species & Canarium asperum & Canarium asperum & Pimelodendron amboinicum & Canarium asperum \\
& DI & 0.16 & 0.05 & 0.11 & 0.09 \\
& IVI & 32.02 & 27.02 & 27.62 & 24.53 \\
Nusa & Number of plots & 6 & 6 & 6 & 6 \\
& Species & Chionanthus ramiflorus & Chionanthus ramiflorus & Canarium asperum & Canarium asperum \\
& DI & 0.42 & 0.30 & 0.39 & 0.43 \\
& IVI & 65.41 & 46.90 & 91.48 & 114.50 \\
Bukide & Number of plots & 6 & 6 & 6 & 6 \\
& Species & Canarium asperum & Chionanthus ramiflorus & Canarium asperum & Canarium asperum \\
& DI & 0.15 & 0.14 & 0.27 & 0.29 \\
& IVI & 35.50 & 24.42 & 81.83 & 88.12 \\
\hline
\end{tabular}

Table 2. The average height of trees and poles at vegetation survey plots on the islands of Salibabu, Nusa, and Bukide, North Sulawesi, Indonesia

\begin{tabular}{lllll}
\hline Islands & Tree height $(\mathbf{m})(\mathbf{m e a n} \pm \mathbf{S D})$ & $\mathbf{n}$ & Pole height $(\mathbf{m})(\mathbf{m e a n} \pm \mathbf{S D})$ & $\mathbf{n}$ \\
\hline Salibabu & $16.971 \pm 4.17$ & 139 & $10.941 \pm 2.34$ & 57 \\
Nusa & $14.476 \pm 3.3$ & 49 & $10.90 \pm 1.94$ & 30 \\
Bukide & $13.97 \pm 2.65$ & 38 & $11.46 \pm 1.9$ & 21 \\
\hline
\end{tabular}


Data on tree level and pole level vegetation is very important in describing the habitat of A. melanotis, this is because, as an arboreal marsupial, A. melanotis utilizes higher level vegetation structure to move and rest, and is highly dependent on forest vegetation density (Repi et al. 2019). This is also supported by Riley (2002) who stated that A. melanotis is highly dependent on primary forest. Therefore, arboreal marsupials are considered vulnerable and sensitive to habitat loss and forest fragmentation (Lancaster et al. 2011; Taylor et al. 2011; Goldingay et al. 2013; Malekian et al. 2015). According to Mortelliti et al. (2011) habitat fragmentation is a main driver of distribution patterns in arboreal rodents, because structural connectivity plays an important role in determining the distribution of arboreal animals in particular. However, the shape and size of the branches also determine the movement of arboreal species (Hyams et al. 2012). By knowing that Canarium asperum and Pimelodendron amboinicum as species with the highest dominance and importance value index on the three islands, it can be assumed that cuscus can access the habitats and exploit of the available habitats. This is because Canarium asperum and Pimelodendron amboinicum are both large trees with branches forming a wide canopy (Djarwaningsih 2002; Djarwaningsih 2004) that provide a connection for the movement of the cuscus. Therefore, the condition of vegetation cover can be an indicator of the existence of cuscus.

The difference in vegetation structure on the three islands is indirectly influenced by the size of the island. In tropical areas, this is related to climate (rainfall and wind) as well as the structure and nutrient content of the soil (Medina et al. 2015). High rainfall causes soil instability, which also drives the height of fallen trees (Jing 2019). This is exacerbated by strong winds which are known to be the cause of the high level of forest damage, especially in the edge areas (Schindler et al. 2012; Mitchell 2013). Furthermore, short direct runoff trajectories of water to the coast increase the chances of being drifted away from tree seeds and soil nutrients. In addition, strong wind forces at high altitudes and near the edge can cause high tree mortality rates which directly change forest structure and composition (Laurance 2008). The combination of these effects results in smaller trees (height and diameter) with a lower density in their distribution. The smaller the island, the higher the effect, so that small islands have a lower vegetation structure than large islands (Medina et al. 2015). This may explain why the average tree height of Salibabu Island is higher than the two other islands.

Based on the diversity index, it is known that Salibabu Island has a high diversity $\left(H^{\prime} \geq 3\right)$, while Nusa Island and
Bukide Island has a medium diversity $\left(\begin{array}{llll}1 & <\mathrm{H}^{\prime} & <3\end{array}\right)$. Furthermore, based on the species richness index, Salibabu Island is classified as high ( $\mathrm{R}>5.0)$, while Nusa Island is classified as low $(\mathrm{R}<3.5)$, and Bukide Island is classified as medium ( $R=3.5-5.0)$. Overall, based on the evenness index, habitat conditions on Salibabu, Nusa, and Bukide Islands are still relatively high and stable $(0.6<\mathrm{E} \leq 1.0)$ (Table 3).

The islands support unique biodiversity which has a high level of endemism. According to Médail (2017), this can be explained by complex interactions between a highly heterogeneous historical biogeography and ecological processes related to diverse island conditions. However, it simultaneously has a lower species richness compared to large islands (Whittaker et al. 2017), this is because, as stated by Blackburn et al. (2016), that islands constitute well-defined but restricted spatial units.

Based on the diversity index, it is known that Salibabu Island supports a higher vegetation diversity compared to Nusa Island and Bukide Island. Differences in diversity, species richness, and evenness on each island may be caused by the extent and characteristics of the island, as explained by Okie and Brown (2009) that the islands have unique and different characteristics. As such, the island's influence on diversity reflects the combined effects of abundance, specialization, and other niche attributes (Okie and Brown 2009), which are a result of the interaction of four key processes: immigration, emigration, speciation, and extinction (Blackburn et al. 2016). Furthermore, based on their research, Okie and Brown (2009) showed that the area of the island and the distance from the mainland were positively correlated with diversity. The size of Salibabu Island, which is considerably larger than Nusa Island and Bukide Island, as well as the difference in the remaining forest area on each island, can be a factor that determines the differences in diversity, species richness, and evenness of existing vegetation types. This is theoretically related to the species-area relationship, which explains that the number of species increases with the area of the island (Blackburn et al. 2016; Matthews et al. 2016; Liu et al. 2020).

Based on the Bray Curtis index, it is known that similar vegetation communities occur on Nusa and Bukide Islands with a similarity distance of 0.51 , while the vegetation community on the island of Salibabu is very different. The similarity distance between Nusa Island and Salibabu is 0.24, while the similarity distance between Bukide Island and Salibabu Island are 0.21 (Table 4). This is also indicated by the results of cluster analysis in the form of a dendrogram showing 2 clusters of different vegetation communities (Figure 2).

Table 3. Diversity index, species richness, and evenness of vegetation communities on the islands of Salibabu, Nusa, and Bukide, North Sulawesi, Indonesia

\begin{tabular}{|c|c|c|c|c|c|c|c|c|c|c|c|c|}
\hline \multirow{2}{*}{ Vegetation type } & \multicolumn{4}{|c|}{ Salibabu } & \multicolumn{4}{|c|}{ Nusa } & \multicolumn{4}{|c|}{ Bukide } \\
\hline & $\mathbf{H}$ & $\mathbf{R}$ & $\mathbf{E}$ & $\mathbf{n}$ & $\mathbf{H}$ & $\mathbf{R}$ & $\mathbf{E}$ & $\mathbf{n}$ & $\mathbf{H}$ & $\mathbf{R}$ & $\mathbf{E}$ & $\mathbf{n}$ \\
\hline Seedling & 3.13 & 5.93 & 0.90 & 186 & 1.65 & 1.66 & 0.75 & 123 & 2.61 & 2.57 & 1.05 & 72 \\
\hline Sapling & 0.06 & 7.17 & 0.02 & 132 & 0.13 & 2.38 & 0.05 & 44 & 0.16 & 3.35 & 0.06 & 36 \\
\hline Pole & 3.12 & 6.43 & 0.95 & 57 & 2.04 & 3.20 & 0.82 & 31 & 2.41 & 3.88 & 0.94 & 22 \\
\hline Tree & 3.32 & 8.30 & 0.89 & 140 & 2.02 & 3.34 & 0.76 & 49 & 2.22 & 3.85 & 0.82 & 38 \\
\hline
\end{tabular}

Note: H: Diversity Index, R: species richness, E: evenness, n: Number of Individuals 
Bray Curtis's similarity index shows that the two vegetation communities of Nusa and Bukide Island are relatively similar, while Salibabu Island has a markedly different vegetation community from the other two islands. The similarity of the vegetation community between Bukide and Nusa Island is in likelihood caused by the proximity of the two islands. Meanwhile, differences in island clusters (Sangihe Islands and Talaud Islands), caused differences in vegetation communities on Salibabu Island compared to the other two islands. Nusa and Bukide Island are only around $1.20 \mathrm{~km}$ apart, while, the distance between Bukide and Salibabu is around $114.95 \mathrm{~km}$ and the distance between Nusa and Salibabu is around $120.80 \mathrm{~km}$ (Table 5).

\section{Temperature and Humidity}

The temperature and humidity of each island were measured every morning, afternoon and evening at each transect location. The average temperature on Salibabu Island is $26.45^{\circ} \mathrm{C}$ with the highest temperature $32.10{ }^{\circ} \mathrm{C}$ and the lowest $21.20^{\circ} \mathrm{C}$, while on Nusa Island the average temperature is $26.73{ }^{\circ} \mathrm{C}$ with the highest temperature 32.50 ${ }^{\circ} \mathrm{C}$ and the lowest $21.50{ }^{\circ} \mathrm{C}$, and on Bukide Island on average temperature of $26.90{ }^{\circ} \mathrm{C}$ with the highest temperature of $32.20{ }^{\circ} \mathrm{C}$ and the lowest of $21.800{ }^{\circ} \mathrm{C}$ (Figure 3). The average relative humidity on Salibabu Island was $86.65 \%$, Nusa Island was $86.40 \%$, and Bukide Island was $85.94 \%$ (Figure 4).
Table 4. Bray Curtis similarity index demonstrating vegetation similarity differences between the islands of Salibu, Nusa, and Bukide, North Sulawesi, Indonesia

\begin{tabular}{lccc}
\hline & Salibu & Nusa & Bukide \\
\hline Salibu & 1.00 & 0.24 & 0.21 \\
Nusa & 0.24 & 1.00 & 0.51 \\
Bukide & 0.21 & 0.51 & 1.00 \\
\hline
\end{tabular}

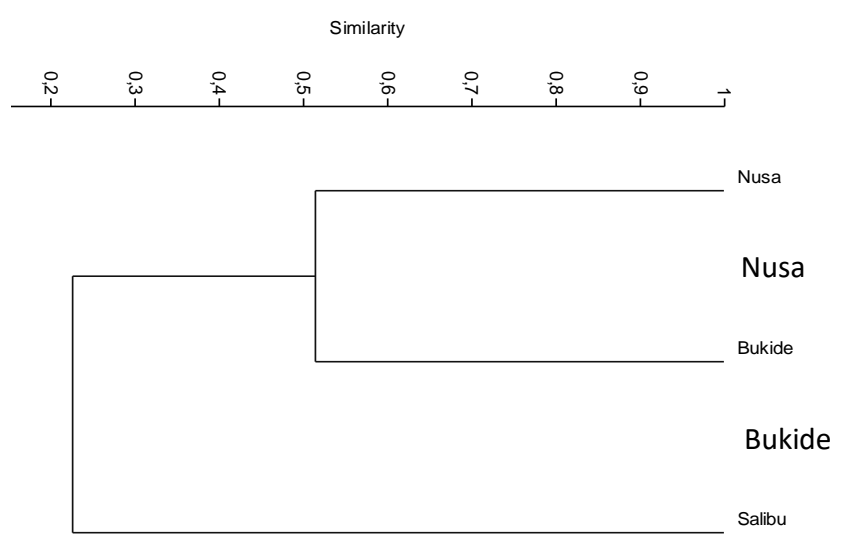

Figure 2. Dendrogram demonstrating Bray-Curtis simil Salibu vegetation communities on the islands of Salibu, Nusa, anu Bukide, North Sulawesi, Indonesia

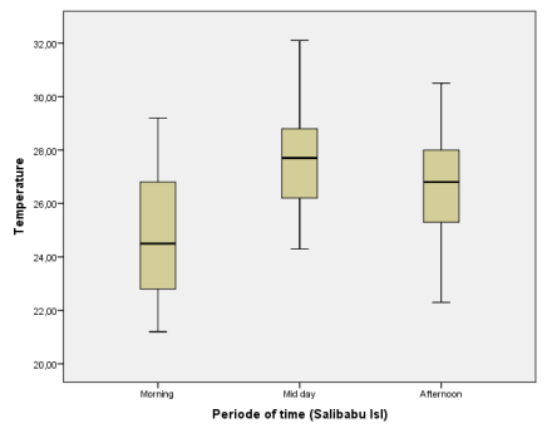

A

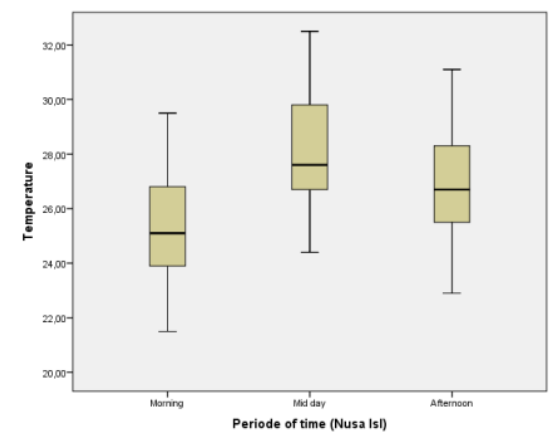

B

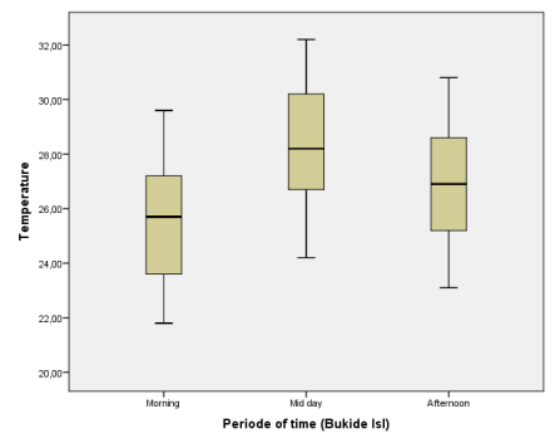

C

Figure 3. Temperature on the study sites. A. Salibabu Island, B. Nusa Island, C. Bukide Island, North Sulawesi, Indonesia

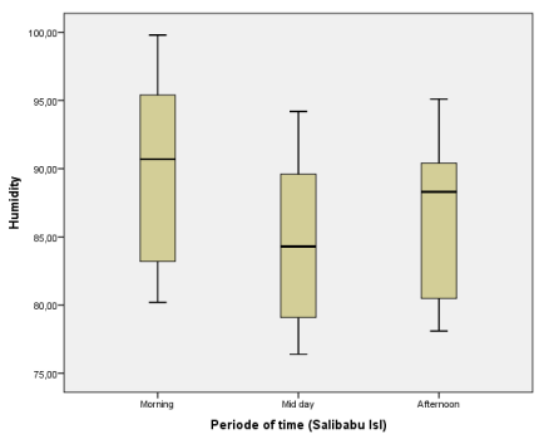

A

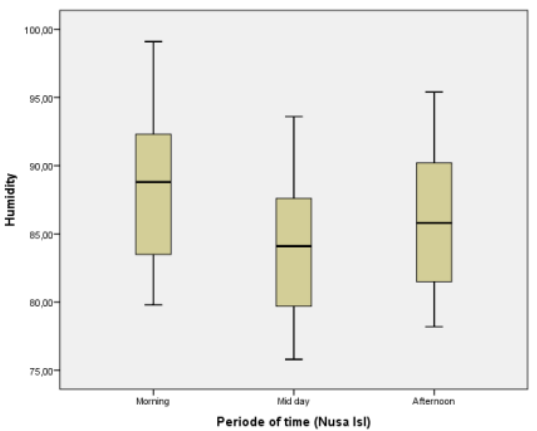

B

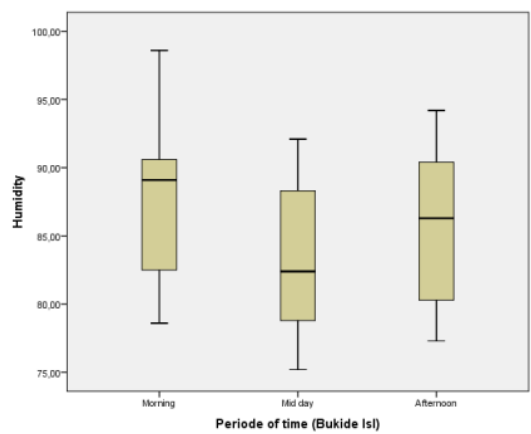

C

Figure 4. Humidity on the study sites. A. Salibabu Island, B. Nusa Island, C. Bukide Island, North Sulawesi, Indonesia 
Table 5. Area of and distance between the islands of Saliababu, Nusa, and Bukide, North Sulawesi, Indonesia

\begin{tabular}{lccc}
\hline Islands & Island area $\left(\mathbf{k m}^{\mathbf{2}}\right)$ & Distance to Sulawesi Island $\mathbf{( k m )}$ & Distance between Islands $(\mathbf{k m})$ \\
\hline Salibabu & 89.97 & 296 & Salibabu-Nusa: $120.80 ;$ \\
Nusa & 4.72 & 237 & Salibabu-Bukide: $114.95 ;$ \\
Bukide & 5.44 & 240 & Nusa - Bukide: 1.20 \\
\hline
\end{tabular}

Temperature and humidity are several climatic factors that have a direct impact on the survival of species. For endotherms, inappropriate temperature has both acute and long-term impacts, affects survival during extreme conditions, and increases costs associated with thermoregulation (Ferreira and Vieira 2014; Rowland et al. 2017). Furthermore, high humidity can lead to inefficient evaporative cooling (Briscoe et al. 2014). In relation to species distribution, Mott (2012) states that the spatial gradient in climate variables is one of the factors limiting the geographic distribution of species.

Repi et al. (2019) reported that there was a strong positive correlation between temperature and resting activity and conversely a strong negative correlation with feeding and moving activities in the behavior of $A$. melanotis. This may be the cause of the small probability of finding the movement of the cuscus during the day. Therefore, further research with the cuscus population survey method at night is necessary, considering that there is no certainty whether it is nocturnal or diurnal (Dwiyahreni et al. 1999; Repi et al. 2019).

The collection of temperature and humidity data, in addition to describing the habitat conditions of cuscus in the three locations, can be used as information for further research, regarding how these animals interact with the biophysical conditions of their habitat, especially climates. As reported by Gaughan et al. (2015), seasonal weather extremes and climate have a direct and indirect influence on the physical and behavioral processes of animals. They also added that understanding how these processes differ between species is a fundamental element of understanding how animals interact with their environment. Related to population, Hlôška et al. (2016) state that climatic factors and related changes of temperature, humidity, and sunshine demonstrably affect the population dynamics of small mammals.

\section{Population distribution}

To determine the distribution of population of $A$. melanotis, a survey was conducted at six locations: Karakelang Island, Salibabu Island, Kabaruan Island, Sangihe Island (Mount Sahendaruman protected forest), Nusa Island, and Bukide Island. From the six islands, cuscus was found on only three islands: Salibabu Island, Nusa Island, and Bukide Island. Based on this research, it is known that on Salibabu island, cuscus is spread throughout the island. Cuscus was found on all transects (six transects), with the highest number of encounters occurring on the D (Musi) transect and the Ayambana transect (Figure 5). On Nusa Island, cuscus is found in the western part of the island. Of the three transects, only two were found with cuscus (Figure 6). Meanwhile, on Bukide Island, cuscus is found in the eastern part of the island. Of the three transects, only two were found cuscus (Figure 7).

The uneven distribution of A. melanotis populations in Nusa Island and Bukide Island, apart from being caused by habitat fragmentation, as shown in Figures 4 and 5, is also due to the extent of the forest and the condition of the available forest. The distribution of cuscuses as arboreal animals clearly depends on the presence of forest ecosystems. This is related to its dependence on trees for nesting, foraging, and dispersal (Lancaster et al. 2011; Malekian et al. 2015). Hannibal and Caceres (2010) stated that vegetation density is a supporting factor as well as a limiting factor in the movement of arboreal animals.

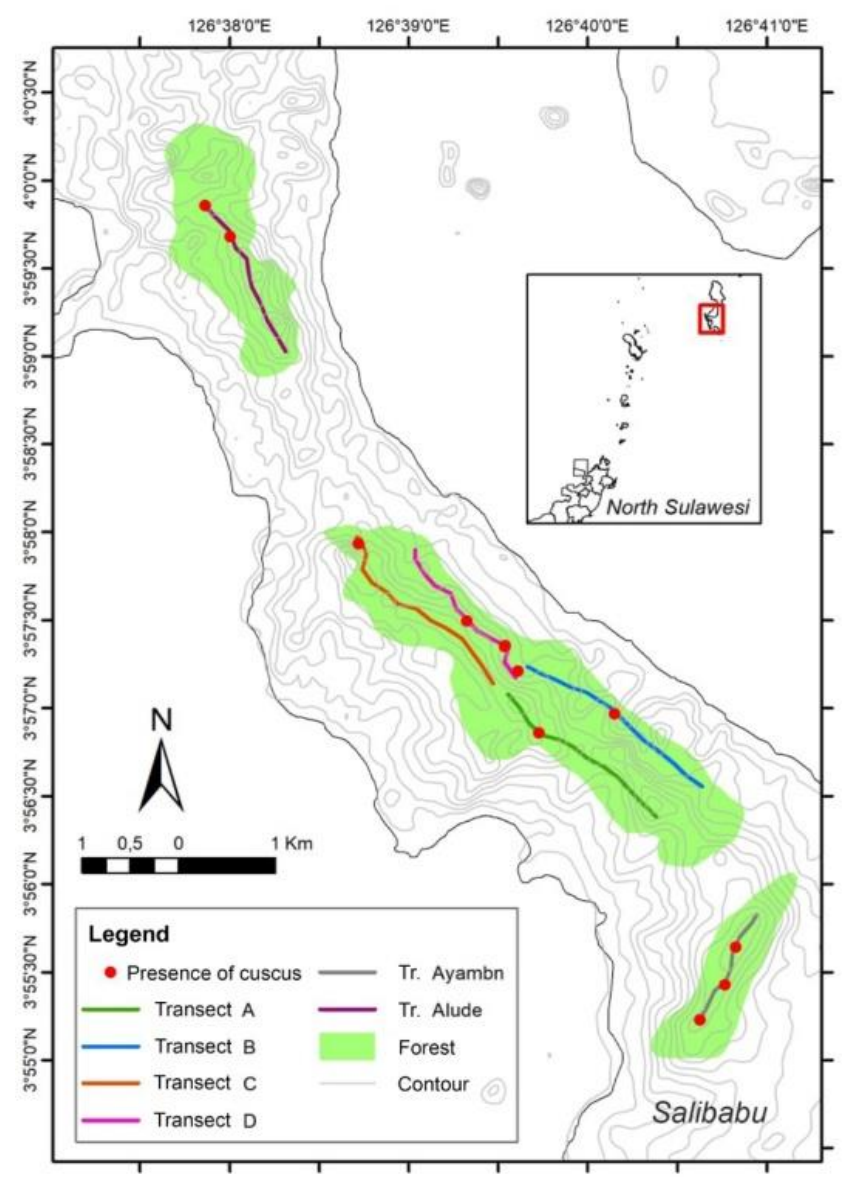

Figure 5. Transects and distributions of A. melanotis on Salibabu Island, North Sulawesi, Indonesia 


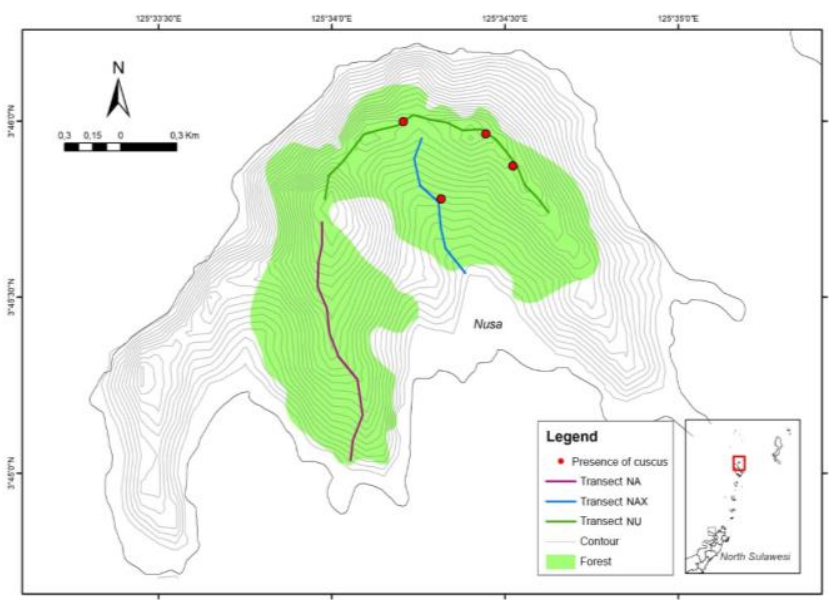

Figure 6. Transects and distributions of Ailurops melanotis on Nusa Island, North Sulawesi, Indonesia

Based on this research, it is known that the remaining forest area on Nusa Island and Bukide Island is much smaller than the forest area on Salibabu Island. This is also related to the smaller areas of the islands of Nusa and Bukide than Salibabu Island. The small area of the two islands, also results in more intense forest use. Furthermore, the high number of encounters with cuscus on the Musi transects on Salibabu Island was more due to the condition of the existing habitat and there are a majority of adherents of Musi indigenous religion who have taboos to consume cuscus meat. Meanwhile, on the Ayambana transect, the high presence of cuscus is due to the dense forest conditions. This is also supported by Kelly et al. (2017), who reported that the remaining primary forest on Salibabu Island is in the Ayambana.

Based on the interviews conducted on Karakelang Island in three locations: Beo, Melonguane, and Rainis (30 respondents) and Kabaruan Island: Mangaran and Bulude (20 respondents), none of them knew that in each of these islands there was talaud bear cuscus, all respondents claimed to know that cuscus was only found on Salibabu Island.

The findings on Salibabu Island, as well as confirming the results of Riley (2002), also provide information on the distribution of cuscus throughout the island. Furthermore, the findings on Nusa Island and Bukide Island, apart from confirming the uncertainty of the existence of this species on Sangihe Island, also provided new data, regarding the distribution of cuscus, which was previously thought to only exist in one location. According to Flannery and Helgen (2016), the existence of A. melanotis on Sangihe must be confirmed, although a bear cuscus has been seen and photographed on Sangihe, no specimen from here is known to exist. Furthermore, they added, confirmation was needed, because the Sangihe islands were separated from the Talaud Islands and located close to Sulawesi Island, where A. ursinus was spread.

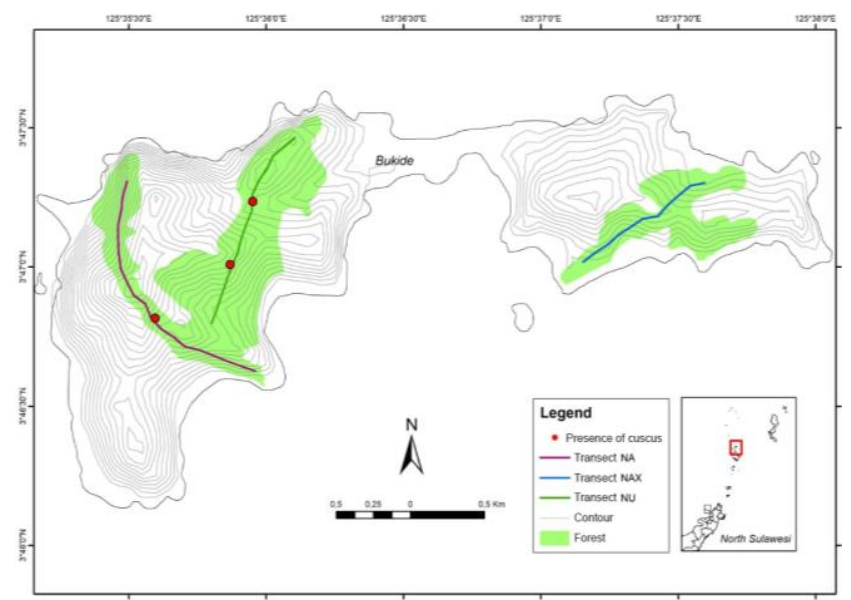

Figure 7. Transects and distributions of Ailurops melanotis on Bukide Island, North Sulawesi, Indonesia

Furthermore, we suspect that most likely this species also exists on Sangihe Island, especially in the Mount Sahendaruman Protection Forest, as reported by Riley (2002). Although the population survey that had been conducted briefly for 14 days on Mount Sahendaruman did not find any individual cuscus, based on the interviews with three villages around the area: Hiung, Ulung Peliang, and Malamenggu (total 15 respondents), found that all respondents knew and claimed to have seen A. melanotis around the Sahendaruman forest area. A total of four respondents claimed to have caught cuscus and as many as nine respondents had consumed it.

Interestingly, the knowledge of Talaud bear cuscus on Sangihe Island was only found in the villages around Mount Sahendaruman. In fact, the location of Mount Sahendaruman is in the south, which is closer to the island of Sulawesi. No sightings of cuscus in the Sahendaruman Mountain Protection Forest is probably caused by topographic and forest cover factors. In addition, Riley (2002) had conducted an intense survey for 120 days at Mount Sahendaruman, Sangihe but found no individual cuscus in nature.

\section{Population density}

Population density estimates of Talaud bear cuscus population on Salibabu Island were obtained through observation on six transects with a total length of $12.7 \mathrm{~km}$. Based on observations with 10 replications for each transect, there were 11 encounters with a total of 19 individuals seen. With a total survey area of $0.76 \mathrm{~km}^{2}$, the population density of $A$. melanotis on Salibabu Island was $3.69 \pm 2.54 \mathrm{ind} / \mathrm{km}^{2}$. Population density on Nusa Island was obtained through observation on three transects with a total length of $3.91 \mathrm{~km}$. Based on observations with 10 replications for each transect, there were four encounters and a total of seven animals were seen. With a total survey area of $0.23 \mathrm{~km}^{2}$, it was found that the population density 
of A. melanotis on Nusa Island was $12.31 \pm 2.58 \mathrm{ind} / \mathrm{km}^{2}$. Population density on Bukide Island was obtained through observations on three transects with a total length of 4.20 $\mathrm{km}$. Based on observations of 10 replications for each transect, there were three encounters and a total of five individuals were seen. With a total survey area of $0.25 \mathrm{~km}^{2}$, it was found that the population density of A. melanotis on Nusa Bukide Island was $7.17 \pm 1.79 / \mathrm{km}^{2}$ (Table 6). The sex ratio on the three islands is Salibabu Island 1: 1.5, Nusa Island 1: 2, and on Bukide Island 1: 1 (Figure 8).

The composition of age and sex ratio based on population observations, consisting only of adult males, adult females and subadults. The absence of infants could be related to the observation time, which did not coincide with the birth season, or it could be due to technical factors of observation. This could relate to the behavior and the marsupial reproductive system, as it is known that the marsupials giving birth to altricial young that typically develop in a pouch (Edwards and Deakin 2012). In addition, it was found that cuscus would move into hiding and then stay still when they were disturbed by the presence of humans, this is similar to the research of Repi et al. (2019) of A. melanotis in Salibabu island and Nugraha and Mustari (2017) of Ailurops ursinus in Tanjung Peropa, Southeast Sulawesi, Indonesia.

The low cuscus population density on these three islands may be explained by the influence of human activities (hunting and habitat degradation). There are many studies that discuss how anthropogenic influences facilitate population decline and even extinction (Yackulic et al. 2011; Mugume et al. 2015; He et al. 2018; TaylorBrown et al. 2019). Furthermore, Habitat fragmentation has a profound effect on species dispersal (reduces individual movements between patches), and subsequently affect population density (Cote et al. 2016), as well as has a large negative effect on biodiversity (Fletcher Jr et al. 2015). Therefore, habitat destruction and fragmentation are the root cause of numerous conservation problems (Resasco et al. 2016).

Based on interviews and observations on the three islands, we found similarities in forms of human activity that have the potential for population decline. First, on all three islands, A. melanotis are the most hunted animals for different purposes (Salibabu; for consumption, Bukide and Nusa; some of it is consumed, partly sold to Sangihe Island or sold/bartered with Filipino fishermen). As known, illegal trade in wildlife smuggled out of Indonesia to the Philippines is common (Shepherd et al. 2018). Second, the development of the human population on the three islands has encouraged land clearing for agriculture and settlements.

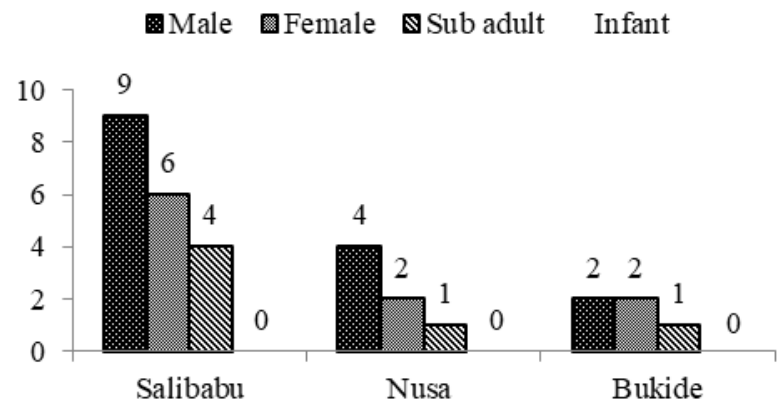

Figure 8. The composition of age and sex ratio of A. melanotis on Salibabu, Nusa and Bukide Islands, North Sulawesi, Indonesia

Table 6. Population density of Ailurops melanotis on the islands of Salibabu, Nusa and Bukide, North Sulawesi, Indonesia

\begin{tabular}{|c|c|c|c|c|c|c|c|c|}
\hline Islands & Transect & $\begin{array}{c}\text { Length } \\
\text { (km) }\end{array}$ & $\begin{array}{l}\text { Width } \\
\text { (km) }\end{array}$ & $\begin{array}{l}\text { Total area } \\
\left(\mathbf{k m}^{2}\right)\end{array}$ & $\begin{array}{l}\text { Replication } \\
\text { (times) }\end{array}$ & $\begin{array}{l}\text { Numbers } \\
\text { seen (ind) }\end{array}$ & $\begin{array}{l}\text { Encounters } \\
\text { (times) }\end{array}$ & $\begin{array}{l}\text { Density } \\
\text { (ind//km²) }\end{array}$ \\
\hline Salibabu & $\begin{array}{l}\text { Musi-A } \\
\text { Musi-B } \\
\text { Musi-C } \\
\text { Musi-D } \\
\text { Ayambn } \\
\text { Alude } \\
\text { Total } \\
\text { Average } \\
\text { Density (ind } / \mathrm{km}^{2} \text { ) }\end{array}$ & $\begin{array}{c}2.2 \\
2.4 \\
2.5 \\
2.1 \\
1.5 \\
2 \\
12.7\end{array}$ & $\begin{array}{l}0.06 \\
0.06 \\
0.06 \\
0.06 \\
0.06 \\
0.06 \\
0.36\end{array}$ & $\begin{array}{l}0.13 \\
0.14 \\
0.15 \\
0.13 \\
0.09 \\
0.12 \\
0.76\end{array}$ & $\begin{array}{l}10 \\
10 \\
10 \\
10 \\
10 \\
10 \\
60\end{array}$ & $\begin{array}{c}1 \\
1 \\
1 \\
6 \\
6 \\
4 \\
19\end{array}$ & $\begin{array}{c}1 \\
1 \\
1 \\
3 \\
3 \\
2 \\
11\end{array}$ & $\begin{array}{c}0.76 \\
0.69 \\
0.67 \\
4.76 \\
6.67 \\
3.33 \\
16.88 \\
2.81 \\
\mathbf{3 . 6 9}\end{array}$ \\
\hline Nusa & $\begin{array}{l}\text { Nusa } 1 \text { (NU) } \\
\text { Nusa } 2 \text { (NA) } \\
\text { Nusa } 3 \text { (NAX) } \\
\text { Total } \\
\text { Average } \\
\text { Density (ind/km²) }\end{array}$ & $\begin{array}{c}1.68 \\
1.33 \\
0.9 \\
3.91\end{array}$ & $\begin{array}{l}0.06 \\
0.06 \\
0.06 \\
0.18\end{array}$ & $\begin{array}{l}0.10 \\
0.08 \\
0.05 \\
0.23\end{array}$ & $\begin{array}{l}10 \\
10 \\
10 \\
30\end{array}$ & $\begin{array}{l}5 \\
0 \\
2 \\
7\end{array}$ & $\begin{array}{l}3 \\
0 \\
1 \\
4\end{array}$ & $\begin{array}{c}4.96 \\
0 \\
3.70 \\
8.66 \\
2.89 \\
\mathbf{1 2 . 3 1}\end{array}$ \\
\hline Bukide & $\begin{array}{l}\text { Bukide } 1 \text { (BUK) } \\
\text { Bukide } 2 \text { (BK) } \\
\text { Bukide } 3 \text { (BKT) } \\
\text { Total } \\
\text { Average } \\
\text { Density (ind/km²) }\end{array}$ & $\begin{array}{c}1.40 \\
1.80 \\
1 \\
4.20\end{array}$ & $\begin{array}{l}0.06 \\
0.06 \\
0.06 \\
0.18\end{array}$ & $\begin{array}{l}0.08 \\
0.11 \\
0.06 \\
0.25\end{array}$ & $\begin{array}{l}10 \\
10 \\
10 \\
30\end{array}$ & $\begin{array}{l}3 \\
2 \\
0 \\
5\end{array}$ & $\begin{array}{l}2 \\
1 \\
0 \\
3\end{array}$ & $\begin{array}{c}3.57 \\
1.85 \\
0 \\
5.42 \\
1.81 \\
\mathbf{7 . 1 7}\end{array}$ \\
\hline
\end{tabular}


Table 7. Estimated population of A. melanotis on Salibabu, Nusa, and Bukide, North Sulawesi, Indonesia

\begin{tabular}{lccc}
\hline Islands & $\begin{array}{l}\text { Representative } \\
\text { habitat area }\left(\mathbf{k m}^{\mathbf{2}}\right)\end{array}$ & $\begin{array}{l}\text { Density } \\
\text { (ind/km²) }\end{array}$ & $\begin{array}{l}\text { Population } \\
\text { estimates (Ind) }\end{array}$ \\
\hline Salibabu & 7.84 & 3.69 & 28.95 \\
Nusa & 1.55 & 12.31 & 19.08 \\
Bukide & 1.45 & 7.17 & 10.40 \\
\hline
\end{tabular}

This is as reported by Riley (2002), who noted this species is highly hunted and spread in fragmented habitats due to high land clearing for agriculture and plantations. Third, the need for wood materials for buildings and firewood, almost all of which come from forests on each island (the cost of buying wood from the other islands is very expensive). Based on these three points, we assume that human activity is very influential in the low population density of A. melanotis.

Furthermore, Owens and Bennett (2000) explain that extinction risk due to human activities can be associated with body size, where species with large body size are more susceptible to hunting, and correlate with generation time. Whereas species with small body sizes are very susceptible to loss of habitat, in relation to the specialization of the species. Hamback et al. (2007) add that although large species are considered to be more sensitive to fragmentation due to greater space use and food resource needs, but with high mobility, large species can use several patches, whereas small species may be very affected by patchy patches, but can use strategies to optimize small habitat use. While intermediate body size species may be most sensitive to fragmentation because they cannot use any strategy.

Population estimates were obtained by extrapolating the density of each island with a representative habitat area (Table 7). Based on the extrapolation, it is known that Salibabu Island has the highest population estimate of 28.95 individuals compared to the estimated population of Nusa Island of 19.08 individuals and Bukide Island of 10.40 individuals.

Overall, the population density of A. melanotis on Salibabu island is higher than Nusa and Bukide Islands. However, the population number of these three islands is very small compared to the population of Sulawesi bear cuscus (A. ursinus) as reported by Wowor et al. (2016) who estimated a population density in Tangkoko Nature Reserve with a total area of $8.74 \mathrm{~km} 2$ as $20.87 \mathrm{ind} / \mathrm{km}^{2}$ with an estimated population of 166.75 individuals.

In addition, the differences in the population of the three islands are of course related to the conditions of each island. As is known that size area and ecosystem of the island are very influential on community diversity and population dynamics, as stated by Duncan and Forsyth (2006) island conditions can affect population resistance, this is related to island area, climate conditions, and habitat modification.

In conclusion, based on this research, it is known that the Talaud bear cuscus (A. melanotis), are distributed across three islands, namely: Salibabu Island, Nusa Island, and Bukide Island, with the highest population density, found on Nusa Island, then on Bukide Island and the lowest on Salibabu Island. Information regarding the geographic distribution, population, and habitat of the Talaud bear cuscus can be used as a basis for conservation efforts of this critically endangered species, particularly the management of animal conservation in small islands. In addition, the results of this study can be used as basic information for further research, especially for biogeography and bioecological research on insular animals. Lastly, we propose the importance of further research on Sangihe Island, specifically in Mount Sahendaruman Protection Forest to determine whether $A$. melanotis occurs on Sangihe Island.

\section{ACKNOWLEDGEMENTS}

The authors would like to thank the people of Salibabu Island, Karakelang Island, Kabaruan Island, Sangihe Island, Nusa Island, and Bukide Island who have welcomed and helped us greatly during our research. Thank you also to Yopie Manderos, Marvel Salindeho, Julio Robot, Irvan Gobel, Hendri Hebimisa, Ronal, Danny, Stenly Pontolowokang, Akbar Habibi, and all friends of Nature Lovers organizations in Sangihe and Talaud, who sincerely helped us with field data collection. Lastly, we also thank the Muhammadiyah University of Gorontalo, for a journal publication grant.

\section{REFERENCES}

Blackburn TM, Delean S, Pyšek P, Cassey P. 2016. On the island biogeography of aliens: a global analysis of the richness of plant and bird species on oceanic islands. Glob Ecol Biogeogr 25: 859-868.

Briscoe NJ, Handasyde KA, Griffiths SR, Porter WP, Krockenberger A, Kearney MR. Tree-hugging koalas demonstrate a novel thermoregulatory mechanism for arboreal mammals. Biol Lett 10: 20140235. DOI: 10.1098/rsbl.2014.0235.

Burgar JM, Stewart FEC, Volpe JP, Fisher JT, Burton AC. 2018. Estimating density for species conservation: Comparing camera trap spatial count models to genetic spatial capture-recapture models. Glob Ecol Conserv 15: e00411. DOI: 10.1016/j.gecco.2018.e00411.

Cote J, Bestion E, Jacob S, Travis J, Legrand D, Baguette M. 2016. Evolution of dispersal strategies and dispersal syndromes in fragmented landscapes. Ecography 40 (1): 56-73. DOI: 10.1111/ecog.02538.

Djarwaningsih T. 2002. Persebaran geografi jenis-jenis Pimelodendron (EUPHORBIACEAE) di Malesia. Berita Biologi 6 (3): 509-514. [Indonesian]

Djarwaningsih T. 2004. Revision of Pimelodendron (Euphorbiaceae) in Malesia. Blumea 49: 407- 423. DOI: 10.3767/000651904X484342.

Duncan RP, Forsyth DM. 2006. Modelling population persistence on islands: Mammal introductions in the New Zealand archipelago. Proc R Soc B 273 (1604): 2969-2975. DOI: 10.1098/rspb.2006.3662.

Dwiyahreni A, Kinnaird M, O'Brien T, Supriatna J, Andayani N. 1999. Diet and activity of the bear cuscus, Ailurops ursinus, in North Sulawesi, Indonesia. J Mammal 80 (3): 905-912. DOI: $10.2307 / 1383259$

EDGE [Evolutionarily Distinct and Globally Endangered species]. 2018. Talaud Bear Cuscus. Retrieved from http: //www.edgeofexistence.org/species/talaud-bear-cuscus/. [2 August 2020]. 
Edwards MJ, Deakin JE. 2012. The marsupial pouch: implications for reproductive success and mammalian evolution. Aust J Zool 61 (1): 41-47. DOI: 10.1071/ZO12088.

Ferreira MS, Vieira MV. 2014. Activity pattern of the neotropical marsupial Didelphis aurita in south-eastern Brazilian Atlantic Forest. Trop Ecol 30: 169-172. DOI: 10.1017/S0266467413000886.

Flannery T, Helgen K. 2016. Ailurops melanotis. The IUCN Red List of Threatened Species 2016: e.T136218A21949526. DOI: 10.2305/IUCN.UK.2016-2.RLTS.T136218A21949526.en. [2 August 2020].

Fletcher Jr RJ, Didham RK, Leite CB, Barlow J, Ewers RM, Rosindell J, Holt RD, Gonzalez A, Pardini R, Damschen EI, Melo FPL, Ries L, Prevedello JA, Tscharntke T, Laurance WF, Lovejoy T, Haddad NM. 2018. Is habitat fragmentation good for biodiversity?. Biological Conservation 226 (10): 9-15. DOI: 10.1016/j.biocon.2018.07.022.

Gaughan JB, Hogan LA, Andrea W. 2015. Thermoregulation in Marsupials and Monotremes. In: Klieve A, Hogan LA, Johnston S, Murray P (eds). Monotremes and Marsupials: Nature's Enigmatic Mammals. Nova Science Publishers, New York.

Goldingay RL, Harrisson KA, Taylor AC, Ball TM, Sharpe DJ, Taylor BD. 2013. Fine-Scale Genetic Response to Landscape Change in a Gliding Mammal. PLoS ONE 8 (12): e80383. DOI: 10.1371/journal.pone.0080383.

Hamback PA, Summerville KS, Steffan-Dewenter I, Krauss J, Englund G, Crist TO. 2007. Habitat specialization, body size, and family identity explain lepidopteran density-area relationships in a cross-continental comparison. Proc Natl Acad Sci USA 104 (20): 8368-8373. DOI: 10.1073/pnas.0611462104.

Hannibal W, Caceres NC. 2010. Use of vertical space by small mammals in gallery forest and woodland savannah in south-western Brazil. Mammalia 74 (3): 247-255. DOI: 10.1515/mamm.2010.007.

He J, Yan C, Holyoak M, Wan X, Ren G, Hou Y, Xie Y, Zhang Z. 2018. Quantifying the effects of climate and anthropogenic change on regional species loss in China. PloS One 13 (7): e0199735. DOI: 10.1371/journal.pone. 0199735.

Heinsohn TE. 2010. Marsupials as introduced species: Long-term anthropogenic expansion of the marsupial frontier and its implications for zoogeographic interpretation. In: Haberle S, Stevenson J, Prebble M (eds.). Altered Ecologies (Terra Australis 32): Fire, climate and human influence on terrestrial landscapes. ANU Press, Australia. DOI: $10.22459 / \mathrm{ta} 32.11 .2010 .09$.

Hlôška L, Chovancová B, Chovancová G, Fleischer P. 2016. Influence of climatic factors on the population dynamics of small mammals (Rodentia, Soricomorpha) on the sites affected by windthrow in the High Tatra Mts. Folia Oecologica 43 (1): 12-20.

Hyams SE, Jayne BC, Cameron GN. 2012. Struktur Habitat Arborea Mempengaruhi Kecepatan Lokomotor dan Pilihan Bertengger Mencit Putih (Peromyscus leucopus). J Exp Zool 9999A: 1-12. DOI 10.1002/jez.1746

Jing X, Chen Y, Pan C, Yin T, Wang W, Fan X. 2019. Erosion Failure of a Soil Slope by Heavy Rain: Laboratory Investigation and Modified GA Model of Soil Slope Failure. Intl J Environ Res Public Health 16 (6): 1075. DOI: 10.3390/ijerph16061075.

Kelly J, Rahman A, Grass I, Tasirin JS, Waltert M. 2017. Avifaunal status updates, range extensions and potential new taxa on the lesser Sangihe and Talaud Islands, Indonesia. Raffles Bull Zool 65 (9): 482 496.

Lancaster ML, Taylor AC, Cooper SJB, Carthew SM. 2011. Limited ecological connectivity of an arboreal marsupial across a forest/plantation landscape despite apparent resilience to fragmentation. Mol Ecol 20: 2258-2271.

Laurance WF. 2008. Theory meets reality: How habitat fragmentation research has transcended island biogeographic theory. Biol Conserv 141 (7): 1731-1744. DOI: 10.1016/j.biocon.2008.05.011.

Leca JB, Gunst N, Rompis A, Soma G, Putra IGAA, Wandia IN. 2013 Population density and abundance of Ebony Leaf Monkeys (Trachypithecus auratus) in West Bali National Park, Indonesia. Primate Conserv 26 (1): 133-144. DOI: 10.1896/052.026.0106.

Liu J, Matthews TJ, Zhong L, Liu J, Wu D, Yu M. 2020. Environmental filtering underpins the island species-area relationship in a subtropical anthropogenic archipelago. J Ecol 108: 424-432. DOI: 10.1111/13652745.13272.

Magurran AE. 2004. Measuring Biological Diversity. Blackwell Publishing Co., Malden, USA.

Malekian M, Cooper SJB, Saint KM, Lancaster ML, Taylor AC, Carthew SM. 2015. Effects of landscape matrix on population connectivity of an arboreal mammal, Petaurus breviceps. Ecol Evol 5 (18): 39393953.

Marques TA, Thomas L, Martin SW, Mellinger DK, Ward JA, Moretti DJ, Harris D, Tyack PL .2013. Estimating animal population density using passive acoustics. Biol Rev Camb Phil Soc 88 (2): 287-309. DOI: $10.1111 /$ brv.12001.

Martin TE, Monkhouse J, O’Connell DP, Analuddin K, Karya A, Priston NEC, Palmer CA, Harrison B, Baddams J, Mustari AH, Wheeler PM, Tosh DG. 2018. Distribution and status of threatened and endemic marsupials on the offshore islands of south-east Sulawesi, Indonesia. Austr Mammal 41 (1): 76-81. DOI: 10.1071/AM17052.

Matthews TJ, Guilhaumon F, Triantis KA, Borregaard MK, Whittaker RJ. 2016. On the form of species-area relationships in habitat islands and true islands. Glob Ecol Biogeogr 25: 847-858. DOI: 10.1111/geb.12269.

Médail F. 2017. The specific vulnerability of plant biodiversity and vegetation on Mediterranean islands in the face of global change. Reg Environ Change 17: 1775-1790. DOI: 10.1007/s10113-017-1123-7.

Medina ES, Vásquez AI, Moreno MP, Torres-González A. 2015. Island effect on diversity, abundance and vegetation structure in the Chocó Region. Acta Bot Bras 29 (4): 509-515. DOI: 10.1590/0102$33062015 \mathrm{abb} 0154$.

Mitchell SJ. 2013. Wind as a natural disturbance agent in forests: a synthesis. Forestry 86 (2): 147-157. DOI: 10.1093/forestry/cps058.

Mortelliti A, Amori G, Capizzi D, Cervone C, Fagiani S, Pollini B, Boitani L. 2011. Independent effects of habitat loss, habitat fragmentation and structural connectivity on the distribution of two arboreal rodents. J Appl Ecol (48) 153-162. DOI: 10.1111/j.13652664.2010.01918.x.

Mott CL. 2010. Environmental constraints to the geographic expansion of plant and animal species. Nature Educat Knowl 3 (10): 72

Mueller-Dombois D, Ellenberg H. 1974. Aims and Methods of Vegetation Ecology. John Wiley \& Sons, New York.

Mugume S, Isabirye-Basuta G, Otali E, Reyna-Hurtado R, Chapman CA. 2015. How do human activities influence the status and distribution of terrestrial mammals in forest reserves? J Mammal 96 (5): 998-1004. DOI: $10.1093 /$ jmammal/gyv104.

Natus IR. 2005. Biodiversity and Endemic Centres. [Dissertation]. Universität Trier, Trier. [German].

Norton-Griffiths M. 1978. Counting animals Handbook No. 1 (2nd ed). African Wildlife Leadership Foundation, Nairobi.

Nugraha R, Mustari AH. 2017. Karakteristik habitat dan jenis pakan kuskus beruang (Ailurops ursinus) di suaka margasatwa tanjung peropa, sulawesi tenggara. J. Wasian 4 (2): 55-68.

Okie JG, Brown JH. 2009. Niches, body sizes, and the disassembly of mammal communities on the Sunda Shelf islands. In: Wake DB, Hadly EA, Ackerly DD (eds) Biogeography, changing climates, and niche evolution. Proc Nat Acad Sci USA 106 (Supplement_2): 1967919684. DOI: 10.1073/pnas.0901654106.

Owens IPF, Bennett PM. 2000. Ecological basis of extinction risk in birds: Habitat loss versus human persecution and introduced predators. Proc Nat Acad Sci USA 97 (22): 12144-12148. DOI: 10.1073/pnas.200223397.

Pielou EC. 1966. The measurement of diversity in different types of biological collections. J Theor Biol 13: 131-144. DOI: 10.1016/00225193 (66)90013-0.

Repi T, Masyud B, Mustari AH, Prasetyo LB. 2019. Daily activity and diet of Talaud bear cuscus (Ailurops melanotis Thomas, 1898) on Salibabu Island, North Sulawesi, Indonesia. Biodiversitas 20 (9): 2636-2644. DOI: 10.13057/biodiv/d200928

Resasco J, Bruna EM, Haddad NM, Banks-Leite C, Margules CR. 2016. The contribution of theory and experiments to conservation in fragmented landscapes. Ecography 40 (1). DOI: 10.1111/ecog.02546.

Riley J. 2002. Mammals on the Sangihe and Talaud Islands, Indonesia, and the impact of hunting and habitat loss. Oryx 36 (3): 288-296. DOI: $10.1017 / \mathrm{S} 0030605302000510$.

Robinson NM, Scheele BC, Legge S, Southwell DM, Carter O, Lintermans M, Radford JQ, Skroblin A, Dickman CR, Koleck J, Wayne AF, Kanowski J, Gillespie GR, Lindenmayer DB. 2018. How to ensure threatened species monitoring leads to threatened species conservation. Ecol Manag Restor 19 (3): 222-229. DOI: 10.1111/emr.12335

Rowland JA, Briscoe NJ, Handasyde KA. 2017. Comparing the thermal suitability of nest-boxes and tree-hollows for the conservationmanagement of arboreal marsupials. Biol Conserv 209: 341-348. DOI: 10.1016/j.biocon.2017.02.006 
Schindler D, Bauhus J, Mayer H. 2012. Wind effects on trees. Eur J For Res 131: 159-163. DOI: 10.1007/s10342-011-0582-5.

Shepherd CR, Sy EY, Janssen J, John M. 2018. Protection from exploitation needed for the endemic Sulawesi Bear Cuscus Ailurops ursinus in Indonesia. J Indon His 6 (2): 30-35.

Smith RJ, Veríssimo D, Isaac NJB, Jones KE. 2012. Identifying Cinderella species: Uncovering mammals with conservation flagship appeal. Conserv Lett 5 (3): 205-212. DOI: 10.1111/j.1755263X.2012.00229.x

Subcommittee on Conservation of Natural Population. 1981. Techniques for the Study of Primate Population Ecology. National Academic Press, Washington DC.

Taylor AC, Walker FM, Goldingay RL, Ball T, van der Ree R. 2011 Degree of Landscape Fragmentation Influences Genetic Isolation among Populations of a Gliding Mammal. PLoS ONE 6 (10): e26651. DOI: 10.1371/journal.pone.0026651.

Taylor-Brown A, Booth R, Gillett A, Mealy E, Ogbourne SM, Polkinghorne A, Conroy GC. 2019. The impact of human activities on Australian wildlife. PLoS One 14 (1): e0206958. DOI: 10.1371/journal.pone.0206958
Tucker G. 2005. Biodiversity evaluation methods. In: Hill D, Fasham M, Tucker G, Shewry M, Shaw P (eds) Handbook of Biodiversity Methods Survey, Evaluation and Monitoring. Cambridge University Press, UK.

Whittaker RJ, Fernández-Palacios JM, Matthews TJ, Borregaard MK, Triantis KA. 2017. Island biogeography: Taking the long view of nature's laboratories. Science 357 (6354): eaam8326. DOI: 10.1126/science.aam8326.

Wowor FM, Kiroh HJ, Rawung V, Wungow RH. 2016. Estimasi kepadatan kuskus beruang (Ailurops ursinus) di Cagar Alam Tangkoko Batuangus Kota Bitung. J Zootek 36 (2): 395-404. [Indonesian]

Yackulic, CB, Sanderson EW, Uriarte M. 2011. Anthropogenic and environmental drivers of modern range loss in large mammals. Proc Natl Acad Sci USA 108 (10): 4024-4029. DOI: 10.1073/pnas.1015097108.

Zipkin EF, Saunders SP. 2017. Synthesizing multiple data types for biological conservation using integrated population models. Biol Conserv 217: 240-250. DOI: 10.1016/j.biocon.2017.10.017. 